DoRey, M. J. (1959). J. gen. Microbiol. 20, 91-104

\title{
Some Properties of a Pectolytic Soil Flavobacterium
}

\author{
BY M. J. DOREY* \\ Department of Microbiology, University of Reading
}

SUMMARY: A pectolytic Flavobacterium sp. isolated from soil is described. It possesses a typical bacterial polygalacturonase but no pectin methyl esterase.

Most previous studies on micro-organisms which decompose the pectic substances of plants have centred round three topics: flax-retting, fruit-juice canning and the soft-rot diseases of plants. The only reported observation on the non-pathogenic pectolytic microflora of soil were made by Wieringa (1949). Wieringa devised a pectate gel plate which used the ability of sodium pectate to gel at neutral $\mathrm{pH}$ values in the presence of calcium ion, thus producing a firm surface which could be streaked with a bacterial culture. On plating dilutions of an unspecified soil on this selective medium Wieringa found large numbers of actinomycetes. It has been assumed, largely from aetiological studies of the organism, that Erwinia carotovora, which causes a soft-rot of plant storage organs, occurs in a wide range of soils; but the support for this theory seems largely to be the report (Kerr, 1953) that 20 soil samples from the North of Scotland all contained this organism. The present paper describes the isolation from soil of a hitherto undescribed organism which is pectolytic, possesses a polygalacturonase but no pectin methyl esterase, and is nutritionally non-exacting. These properties made it a suitable tool for more detailed studies on the production and properties of the polygalacturonase.

\section{METHODS}

Soil samples were collected aseptically in sterile containers and were tested with the minimum of delay. The pectate gel medium was prepared after the method described by Richards \& Fouad (1954) except that $2 \%$ (w/v) sodium pectate was used for pouring plates for streaking. The soil percolator used was after a model devised by Dr G. Metcalfe (private communication), similar in essentials to that of Lees (1949), but with the soil column and the reservoir plugged with non-absorbent cotton wool, thus making the apparatus simpler and more adjustable. The maintenance of aseptic conditions was aided by using, to circulate the fluid, positive air pressure from a small pump, instead of suction.

Pectin (Brown Ribbon brand) and sodium pectate (Red Ribbon brand) were obtained from Unipectin Ltd., Zurich, and were purified in the manner described by Wood (1955). The methoxyl content of these substances was estimated by Zinn's (1955) modification of the Zeisel technique.

\footnotetext{
* Present address: Glaxo Laboratories Ltd., Ulverston, Lancashire.
} 
Viscosity measurements were made with a No. 2 Viscometer (British Standards No. 188) in a water bath at $\mathbf{2 5}^{\circ}$; the time taken for water to run through was 19-20 sec. and for pectin solutions between $28 \mathrm{sec}$. and $3 \mathrm{~min}$.

Assay of polygalacturonase. A plate assay devised for fungal polygalacturonase by Dingle, Reid \& Solomons (1953) was adapted for assaying the bacterial enzyme. Sodium pectate $(1 \%, \mathrm{w} / \mathrm{v})$ in $\mathbf{0} \cdot 2 \mathrm{M}$-tris (2-amino-2-hydroxymethylpropane-1:3-diol) + hydrochloric acid buffer ( $\mathrm{pH} \mathrm{8.0),} \mathrm{with} 0.01 \%(\mathrm{w} / \mathrm{v})$ salicylanilide to inhibit micro-organisms, was solidified with $1.5 \%(\mathrm{w} / \mathrm{v})$ waterwashed agar; plates $(9 \mathrm{~cm}$. diam.) were poured with $10 \mathrm{ml}$. of this medium. The material to be tested was taken up in 'fish spines' (capacity 0.04 ml.) and 12 spines used on each plate. The concentration of calcium in the medium was such that the addition of more calcium to test material only depressed enzyme activity. The plates were incubated for $18 \mathrm{hr}$. at $37^{\circ}$ and developed by flooding with $5 \mathrm{~N}-\mathrm{HCl}$. Clear circular zones where the sodium pectate had been hydrolysed were revealed round the spines, surrounded by a denser ring on a faintly opaque ground. Washing of the agar and purification of the sodium pectate markedly improved the sharpness of definition of the inner zone, the diameter of which was measured. With this test a distinct zone of activity was detected with culture fluid diluted to $1 / 512$ in tris buffer (=0.00008 ml. culture fluid). Arbitrary 'spine-plate units' of polygalacturonase activity were calculated by squaring the radius $(\mathrm{mm}$.) of the clear zone, and determining graphically the quantity of enzyme present relative to the amount which would give a zone radius of $5 \mathrm{~mm} .(=1$ unit). A further test plate in which the calcium concentration was controlled was devised by using silica gel in place of agar. A layer of silica sol (Smith, 1951) containing the desired amount of calcium as $\mathrm{CaCl}_{2}$, with $\mathrm{NaCl}$ added when necessary to assist gelling, was poured into a Petri dish; when gelled, a further layer of sol containing sodium pectate (final concentration $0.5 \%, \mathrm{w} / \mathrm{v}$ ) and tris buffer $(\mathrm{pH} 8$ ) was poured on top. The culture filtrate tested was freed from $\mathrm{Ca}^{++}$by passage through a mixed ion-exchange resin column containing IRC 50 and IR $4 \mathrm{~B}$ (Rohm and Haas, Philadelphia, U.S.A.); the enzyme content was unaffected by this treatment. For permanent preparations of agar test plates the material was floated out of the dish, captured on a glass lantern slide and allowed to dry at room temperature (Rondle \& Carman, 1956). The slides were stained for $10 \mathrm{~min}$. with $1 \%(\mathrm{w} / \mathrm{v})$ safranin, washed until the stain remained only in the background, dried and stored.

Bacterial culture filtrates were tested for the presence of pectin methyl esterase by a qualitative method devised by Smith (1958) which relies on the detection of a decrease in $\mathrm{pH}$ value of the enzyme + substrate mixture because of the release of acidic groups.

Organisms. For use in comparative determinative tests, cultures of Flavobacterium spp. were obtained from various sources. The National Collection of Industrial Bacterial (NCIB) supplied 9 strains : no. 8535 (F.aquatile); 8185 $(F$. arborescens); 8204 (F. aurantiacum); 8205 (F. denitrificans); 8207 (F. sulphureum); 8615 (Pseudomonas putrificans, an organism which was classified in the past as Flavobacterium); 8188 (F. suaveolens) 8186 (F. esteroaro- 
maticum); 8187 (F. flavescens). Dr E. Windle Taylor (Metropolitan Water Board, London) supplied a culture of $F$. aquatile (NCTC 9758), which Weeks (1955) pronounced to be identical with the original published description, in contrast to all other strains so named. A Flavobacterium sp. which produced L forms was obtained from Dr L. Dienes (Massachusetts General Hospital, Boston, Mass., U.S.A.), but unfortunately the culture as received no longer appeared to possess this property. A Flavobacterium sp. which degraded $\alpha$-conidendrin was obtained from $\mathrm{Dr}$ W. A. Konetzka (Indiana University, Bloomington, Indiana, U.S.A.), who also supplied a sample of $\alpha$-conidendrin. F. resinovorum which degraded rosin was obtained from Dr P. Daste (University of Paris). Mr W. K. Smith and Dr C. B. Taylor (Imperial Chemical Industries Ltd., Akers Laboratory, Welwyn, Hertfordshire) provided several cultures of Erroinia carotovora and Xanthomonas campestris. A culture labelled F. aquatile, isolated by the late Dr T. Richards from a water sample, was also tested.

\section{RESULTS}

Thirty-one samples were collected in the Thames Valley and Cotswolds from relatively undisturbed sites (woodland and pasture, but not arable land). Samples were percolated in the Metcalfe modification of the apparatus of Lees with $1 \%$ pectin solutions and the flora in the reservoir fluid was examined microscopically. After 4 days of percolation at room temperature a mixed flora developed and the pectin was attacked; the soil column was then washed for $6 \mathrm{hr}$. with sterile distilled water, and fresh pectin solution percolated. In $18 \mathrm{hr}$. large numbers of non-motile Gram-negative rods $(4-5 \times 0.5 \mu)$ appeared, and samples of the microscopically pure percolate were streaked on pectate gel.

Later it was found more convenient to scatter soil crumbs directly on plates of pectate gel medium. In this case regions of liquefaction developed around the crumbs after 3 days at $25^{\circ}$; microscopically a mixed flora was observed in which a long Gram-negative rod predominated in the early stages. This mixed culture was re-streaked on pectate gel medium. Material from isolated regions of liquefaction (=isolated colonies of the pectolytic rod) was re-streaked on pectate gel medium, and finally on yeast extract agar. Subcultures of single colonies from these latter plates behaved as pure cultures. In every case the organism isolated was a pectolytic non-motile Gram-negative non-sporing catalase-positive rod, possessing a yellow pigment, producing neither acid nor gas in sugar media containing peptone, but producing acid from some sugars in defined medium without peptone. It grew well on ordinary laboratory media, and produced no change in litmus milk. The organism was therefore regarded as a flavobacterium.

In one isolation experiment dilutions of a soil sample were plated on pectate gel medium, and a large number of actinomycete colonies and a few fungi were observed on these plates. No attempt was made to isolate pectolytic anaerobes. The aerobic pectin degraders Bacillus polymyxa and Erwinia carotovora did not appear on the plates, although stock cultures of these 
organisms grew well on the pectate gel medium. The addition of bile salts to the pectate gel medium suppressed the flavobacterium and resulted in the isolation of a pseudomonad; $\boldsymbol{E}$. carotovora was not found.

Twenty-five isolates of what appeared to be pectolytic flavobacteria, derived from 13 soil samples, were studied in more detail. In addition, selected cultures of these organisms were compared with a number of strains of named flavobacteria obtained from culture collections and from individual workers. Examination showed that the organisms listed as Flavobacterium spp. formed a heterogeneous group. Some organisms were Gram-positive (most only transiently so) and others were Gram-negative. There seems no reason for including Gram-positive organisms in the genus Flavobacterium when these can all be included in the genus Corynebacterium. Flavobacterium sulphureum NCIB 8207 was manifestly no longer like the organism originally described; as received it was identified as a strain of Bacillus circulans. Pseudomonas putrificans NCIB 8615 was included in the study since it has at times been classified as a Flavobacterium sp.; this was one of the organisms which were Gram-positive in very young cultures.

In view of the work of Weeks (1955) Dr Windle Taylor's culture of Flavobacterium aquatile was accepted as a quasi type species of the genus. Some of the more significant results obtained are recorded in Table 1. The eight strains from soil $(69,72,76,81,85,87,91,94)$ formed a homogeneous group which differed significantly from other Flavobacterium spp., but were sufficiently similar, especially in pigment production, to be regarded as members of that genus. They are, therefore, designated a new species, with the specific epithet pectinovorum, derived from pectinus-pectin and vorare-to swallow.

\section{Flavobacterium pectinovorum n.sp.}

All observations at $25^{\circ}$ unless otherwise stated.

Gram-negative, non-motile, non-capsulated, non-sporing rods $3 \times 0.5 \mu$ in young cultures in nutrient broth and pectin-containing media, outline regular, end walls rounded, becoming irregular with forms up to $15 \mu$ long in older cultures. Colonies on yeast extract agar at 2 days $0.5 \mathrm{~mm}$. diameter, circular, convex, matt, pale yellow, margin lobed. On pectate gel medium colonies visible at 2 days as depressions in the medium, which later liquefied; odour sweet, rich, fruity. Good growth on cooked potato.

Yellow pigment, produced on all media, behaved as a carotenoid alcohol, moving as a single band on a chalk column; absorption peaks in carbon disulphide at 404, 434 and $462 \mathrm{~m} \mu$.

Indole, methyl red and Voges-Proskauer tests negative; no growth in Koser's citrate. Ammonia not produced in peptone water or arginine broth; $\mathrm{H}_{2} \mathrm{~S}$ not produced from peptone water + cysteine. Nitrate reduced to nitrite but not to nitrogen. Gelatin stabs incubated at room temperature: crateriform liquefaction in $\mathbf{5}$ days, stratiform in $\mathbf{2}$ weeks. Frazier's gelatin hydrolysed, tributyrin hydrolysed; pectate gel liquefied, horse blood not lysed, methylene blue not reduced. Catalase positive, though rather weak. Litmus 
F. flavescens $+1+t++1++1|1+1|+t+1|1| 1|1| 1|1| 1 \mid 1+t+1$

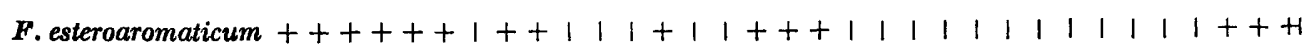

F. suaveolens $+1++++1++111+11+1+11111111+111+++1$ Ps. putrificans $+1++++1++111+11+++11111111+111+++1$ F. sulphureum $11++++11+1|1| 1 \mid+++11+111+1+111+1+$

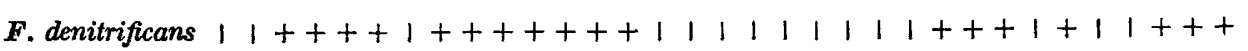
F. aurantiacum $++1+1+11+11+1+1|1+1| 1|1| 1|1+1|+1+$ F. arborescens $t+t+t+1++111+11++t++1+1|1|+111+t+$ F. aquatile $3 t+t+t+1+t|1| 1+1|+t+1| 1|1| 1|1| 1|1| 1+t+$ F. aquatile $2++1+t+1++\begin{array}{lllllllllll}2 & 1 & 1 & 1 & 1 & 1 & 1 & 1 & 1 \\ + & 1 & 1 & 1 & 1 & 1 & 1 & 1 & 1+t\end{array}$ F. sp (L forms) $|1|+++|1++1| 1|1+| 1|1+| 1|+| 1|1|+11$

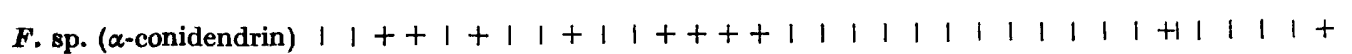
F. resinovorum $11+1+1+11+11++1+11111111+111+1++1+$

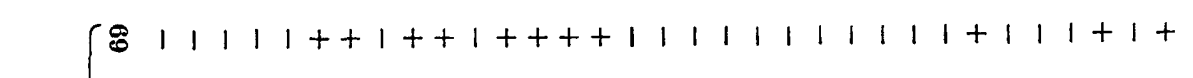
空 $11111++1++1++1|1| 1|1| 1|1| 1+1 \mid 1+1+$

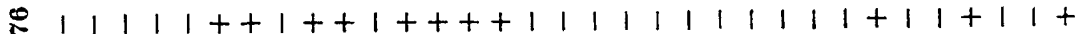
$\infty \quad 1|1| 1+t+t+1+t+t+1|1| 1|1| 1|1|+t 1+11+$

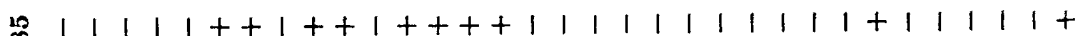
$\infty 11|1|+t+t+1+t+t+1|1| 1|1| 1|1+1|+11+$

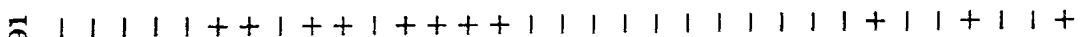
s $11111+t+t+1+t+t+1|1| 1|1| 1|1| 1+11+11+$

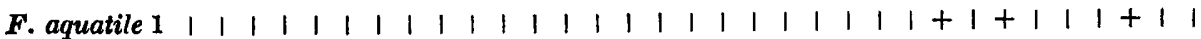


milk in 5 days clearing 1-2 mm. at top; in 10 days soft curd and litmus partially reduced, reaction neutral; then shifting slowly acid in 1-2 months.

Trace of acid from carbohydrates added to peptone media; in media containing only carbohydrate and inorganic salts, acid from glucose and maltose (5 days), sucrose, lactose, xylose, arabinose and inulin (12 days), no growth in salicin or glycerol. A few strains grew and produced acid from salicin and glycerol; one strain did not grow with xylose or arabinose as sole carbon and energy source.

Optimum temperature $25^{\circ}$, good growth at $30^{\circ}$, none at $37^{\circ}$; thermal death point $45 \% 10 \mathrm{~min}$. Growth in peptone water containing $\mathrm{NaCl} 0 \cdot 1$ to $1 \%(\mathrm{w} / \mathrm{v})$, not in $3 \%$. Urea poorly utilized as a $\mathrm{N}$ source, if at all; $\mathbf{N H}_{4}{ }^{+}$utilized: ammonia not liberated from Christensen's urea medium. No growth anaerobically.

Distinctive characters : able to grow on medium containing pectic substances as sole carbon source. Possesses an inducible polygalacturonase.

Stock cultures maintained on yeast extract and glucose yeast extract agar died, often within a week of inoculation; but cultures maintained in media including pectic materials remained viable at room temperature for more than a year. When large inocula were seeded on yeast extract agar plates only a few colonies developed, suggesting that the medium contained inhibitory material. The addition of laked red cells from $0.002 \mathrm{ml}$. horse $\mathrm{blood} / \mathrm{ml}$. medium was sufficient to relieve this inhibition, as were purified horse liver catalase at a final concentration of $0.03 \mathrm{mg} . / \mathrm{ml}$. and $\mathrm{MnO}_{2}$; it was therefore concluded that the inhibitor present in the nutrient agar was hydrogen peroxide (Proom, Woiwod, Barnes \& Orbell, 1950).

Strain no. 81 was designated as the type and deposited with the National Collection of Industrial Bacteria.

\section{Production of polygalacturonase}

Experiments were performed to determine the conditions under which Flavobacterium pectinovorum and Erwinia carotovora produced maximum quantities of polygalacturonase. Organisms were grown aerobically in $25 \mathrm{ml}$. medium in $100 \mathrm{ml}$. flasks shaken at 100 strokes $/ \mathrm{min} .(2 \mathrm{~cm}$. throw $)$ in a water bath at $25^{\circ}$. The inoculum was $0.1 \mathrm{ml}$. of a $25 \mathrm{hr}$. culture in yeast-extract peptone medium. $F$. pectinovorum isolate 81 was the strain used throughout; in many experiments $E$. carotovora (Dr Taylor's strain, numbered $16 \mathrm{~F}$ here) was compared with it, and in a few cases other strains of $E$. carotovora were used. The medium contained ( $\%, \mathrm{w} / \mathrm{v}): \mathrm{NH}_{4} \mathrm{H}_{2} \mathrm{PO}_{4}, 0.2 ; \mathrm{MgSO}_{4} .7 \mathrm{H}_{2} \mathrm{O}, 0.02 ; \mathrm{MnSO}_{4} .4 \mathrm{H}_{2} \mathrm{O}, 0.002$; $\mathrm{FeCl}_{3}, 0.0005 ; \mathrm{CaCl}_{2}, 10^{-3} \mathrm{M}(=0.001 \%)$ except where otherwise stated; bromthymol blue $1 \cdot 6 \%(\mathrm{w} / \mathrm{v})$ ethanolic solution, $0 \cdot 1 \mathrm{ml}$. To this basal solution were added different amounts of peptone or yeast extract, and $1 \%(\mathrm{w} / \mathrm{v})$ of carbohydrate (glucose, galacturonic acid, pectin, sodium pectate). The carbohydrate and phosphate solutions were autoclaved separately and added aseptically to the solution of salts with or without peptone and yeast extract. The pH value of cultures was noted daily, and where necessary adjusted with sterile $\mathrm{N}-\mathrm{NaOH}$ or $\mathrm{HCl}$. It was difficult to adjust aseptically the $\mathrm{pH}$ value of $25 \mathrm{ml}$. 
quantities of fluid, and in some cases it was impossible to maintain the $\mathbf{p H}$ value within the desired range by this method. Where the $\mathrm{pH}$ value varied by more than $\mathbf{0 . 2}$ unit in spite of correction, this was recorded. The amount of polygalacturonase was measured daily by the spine plate technique. Experiments lasted 2 or 3 days; in nearly all cases maximum enzyme production was achieved on the second day and later experiments were therefore run only for 2 days. At the end of the experiment $10 \mathrm{ml}$. samples were centrifuged and the organisms resuspended in Ringer's solution. The amount of material present was estimated nephelometrically by means of a previously constructed calibration curve. In other experiments the number of living organisms was estimated daily by the Miles \& Misra (1938) method. Some of the data obtained are recorded in Table 2.

Flavobacterium pectinovorum isolate 81 , and Erwinia carotovora $16 \mathrm{~F}$ were grown in media containing the inorganic salts noted above, together with $1 \%(w / v)$ of one of the following substances or mixtures: glucose, sodium pectate, peptone, peptone + glucose, peptone+sodium pectate; at five $\mathrm{pH}$ values : $7 \cdot 8,7 \cdot 4,7 \cdot 0,6 \cdot 6$ and $6 \cdot 2$. The results at $\mathrm{pH} 7 \cdot 4$ are recorded in lines 1 to 10 , Table 2. With glucose as carbon source both cultures grew poorly without peptone; with added peptone $F$. pectinovorum isolate 81 produced no enzyme, but $\boldsymbol{E}$. carotovora $16 \mathrm{~F}$ produced up to 4.7 spine plate units. With peptone alone isolate 81 again produced no enzyme, but $E$. carotovora $16 \mathrm{~F}$ produced up to $8 \cdot 6$ units. E. carotovora $16 \mathrm{~F}$ did not grow on sodium pectate without added peptone, but isolate 81 grew well and produced up to $7 \cdot 7$ units. Here the $\mathrm{pH}$ value remained fairly stable and below $\mathrm{pH} \mathbf{7 \cdot 0}$ enzyme was produced very slowly and in small amounts, and not at all at a $\mathrm{pH}$ value $6 \cdot 2$. With added peptone isolate 81 only produced enzyme (up to 14 units) at the lower pH values, but $\boldsymbol{E}$. carotovora $16 \mathrm{~F}$ produced enzyme (up to 65 units) over the whole range. In all cases the $\mathrm{pH}$ value increased rapidly, and it seems likely that polygalacturonase produced by $F$. pectinovorum isolate 81 is more unstable above $\mathrm{pH} 8$ than is the enzyme produced by $\boldsymbol{E}$. carotovora $16 \mathrm{~F}$. The latter organism produced polygalacturonase at $\mathrm{pH} 6 \cdot 2$, but isolate 81 not until the $\mathrm{pH}$ value had risen (uncontrolled) above 7 . The optimum $\mathrm{pH}$ value for enzyme production by both organisms when growing was $\boldsymbol{7 \cdot 4 - 7 \cdot 6}$.

Flavobacterium pectinovorum isolate 81 was grown in various media compounded as follows: sodium pectate $1 \%(\mathrm{w} / \mathrm{v})+$ peptone at $0,0 \cdot 01,0 \cdot 1,0 \cdot 2$, 0.5 , or $1 \%(\mathrm{w} / \mathrm{v})$; with or without yeast extract at $0.0003,0.03,0.06,0.15$ or $0.3 \%(\mathrm{w} / \mathrm{v})$; inorganic salts as previously recorded; initial $\mathrm{pH} 7 \cdot 0$, not adjusted during growth. The optimum peptone concentration for polygalacturonase production was in the range $0.01-0.2 \%$; the addition of yeast extract made only a slight difference; optimum enzyme concentration was obtained with $0.1 \%(\mathrm{w} / \mathrm{v})$ peptone $+\mathbf{0 . 0 3} \%(\mathrm{w} / \mathrm{v})$ yeast extract. The calcium concentration was varied in a further experiment with isolate 81 grown on a medium containing sodium pectate $1 \%$, peptone $0 \cdot 1 \%$, yeast extract $0.03 \%(\mathrm{w} / \mathrm{v})$ and inorganic salts, at pH 7.5. Good yields of enzyme were obtained throughout the range studied (nil to $10^{-2} \mathrm{M}$-calcium added).

The optimum temperature for enzyme production was determined with 
Table 2. Production of polygalacturonase by Flavobacterium pectinovorum isolate 81 and Erwinia carotovora $16 \mathrm{~F}$ in shake flask cultures under different conditions

\begin{tabular}{|c|c|c|c|c|c|c|c|c|c|c|c|}
\hline \multirow{2}{*}{$\begin{array}{l}\text { Orga- } \\
\text { nism }\end{array}$} & \multirow{2}{*}{$\begin{array}{l}\text { Pep- } \\
\text { tone } \\
(\%)\end{array}$} & \multirow{2}{*}{$\begin{array}{c}\text { Yeast } \\
\text { extract } \\
(\%)\end{array}$} & \multirow{2}{*}{$\begin{array}{l}\text { Carbon } \\
\text { source } \\
(\%)\end{array}$} & \multirow[b]{2}{*}{$\underset{\text { value }}{\mathbf{p H}}$} & \multirow{2}{*}{$\begin{array}{l}\text { Inoculum } \\
\times 10^{-8} \\
\text { organisms }\end{array}$} & \multicolumn{2}{|c|}{$\begin{array}{l}\text { Polygalacturonase } \\
\text { spine plate } \\
\text { units }\end{array}$} & \multirow{2}{*}{$\begin{array}{l}\mathrm{pH} \\
\text { rose or } \\
\text { fell to }\end{array}$} & \multicolumn{2}{|c|}{$\begin{array}{c}\text { Bacterial } \\
\text { numbers } \times 10^{-7}\end{array}$} & \multirow{2}{*}{$\begin{array}{l}\text { Temp. } \\
\left({ }^{\circ}\right)\end{array}$} \\
\hline & & & & & & $(24 \mathrm{hr})$. & (48 hr.) & & $(24 \mathrm{hr})$. & $(48 \mathrm{hr})$. & \\
\hline \multirow[t]{5}{*}{$16 F$} & 0 & 0 & $\mathbf{G}$ & $7 \cdot 4$ & 14 & o & 0 & $7 \cdot 0$ & $0 \cdot 37$ & 1.85 & 25 \\
\hline & 0 & o & $\mathbf{N}$ & $7 \cdot 4$ & $\mathbf{1} \cdot \mathbf{1}$ & 0 & $\mathbf{0}$ & - & $<0 \cdot 1$ & $<0.1$ & - \\
\hline & 1 & $\mathbf{0}$ & - & $7 \cdot 4$ & 14 & $2 \cdot 2$ & $9 \cdot 2$ & $8 \cdot 3$ & 14 & 190 & - \\
\hline & 1 & $\mathbf{0}$ & $\mathbf{G}$ & $7 \cdot 4$ & 14 & $0 \cdot 1$ & $4 \cdot 3$ & $7 \cdot 7$ & 67 & 910 & - \\
\hline & 1 & $\mathbf{0}$ & $\mathbf{N}$ & $7 \cdot 4$ & $1 \cdot 1$ & $21 \cdot 5$ & 49 & $8 \cdot 6$ & 15 & 1400 & - \\
\hline \multirow[t]{15}{*}{81} & 0 & $\mathbf{0}$ & $\mathbf{G}$ & $7 \cdot 4$ & 80 & $\mathbf{0}$ & 0 & $6 \cdot 8$ & $2 \cdot 3$ & $19 \cdot 5$ & - \\
\hline & 0 & $\mathbf{0}$ & $\mathbf{N}$ & $7 \cdot 4$ & $3 \cdot 1$ & $\mathbf{0}$ & $4 \cdot 2$ & - & $\mathbf{2 \cdot 8}$ & 35 & - \\
\hline & 1 & $\mathbf{0}$ & - & $7 \cdot 4$ & 80 & $\mathbf{0}$ & 0 & $8 \cdot 2$ & 18 & 650 & - \\
\hline & 1 & $\mathbf{0}$ & G & $7 \cdot 4$ & $3 \cdot 1$ & 0 & $\mathbf{0}$ & $6 \cdot 2$ & $\mathbf{1} \cdot \mathbf{1}$ & 620 & - \\
\hline & 1 & o & $\mathbf{N}$ & $7 \cdot 4$ & $3 \cdot 1$ & o & o & $8 \cdot 2$ & 75 & 320 & - \\
\hline & $0 \cdot 01$ & 0 & $\mathbf{N}$ & $7 \cdot 0$ & $5 \cdot 1$ & 0 & $11 \cdot 8$ & - & - & 196 & - \\
\hline & $0 \cdot 01$ & 0.003 & $\mathbf{N}$ & $7 \cdot 0$ & $5 \cdot 1$ & 0 & $9 \cdot 1$ & - & - & 140 & - \\
\hline & $0 \cdot 1$ & 0 & $\mathbf{N}$ & $7 \cdot 0$ & $5 \cdot 1$ & 0 & $9 \cdot 1$ & $7 \cdot 4$ & - & 320 & - \\
\hline & $0 \cdot 1$ & 0.03 & $\mathbf{N}$ & $7 \cdot 0$ & $5 \cdot 1$ & 0.8 & 23 & $7 \cdot 6$ & - & 330 & - \\
\hline & 0.2 & 0 & $\mathbf{N}$ & $7 \cdot 0$ & $5 \cdot 1$ & 0 & $11 \cdot 8$ & $7 \cdot 5$ & - & 320 & - \\
\hline & $0 \cdot 2$ & 0.06 & $\mathbf{N}$ & $7 \cdot 0$ & $5 \cdot 1$ & 0 & $9 \cdot 9$ & $7 \cdot 7$ & - & 320 & - \\
\hline & $0 \cdot 5$ & 0 & $\mathbf{N}$ & $7 \cdot 0$ & $5 \cdot 1$ & 0 & $7 \cdot 5$ & $7 \cdot 8$ & - & 340 & - \\
\hline & 0.5 & $0 \cdot 15$ & $\mathbf{N}$ & $7 \cdot 0$ & $5 \cdot 1$ & 0 & 7.5 & $7 \cdot 9$ & - & 380 & - \\
\hline & 1 & 0 & $\mathbf{N}$ & $7 \cdot 0$ & $5 \cdot 1$ & 0 & 0.6 & $8 \cdot 1$ & - & 340 & - \\
\hline & 1 & $0 \cdot 3$ & $\mathbf{N}$ & $7 \cdot 0$ & $5 \cdot 1$ & 0 & 0 & $8 \cdot 2$ & - & 480 & - \\
\hline \multirow[t]{4}{*}{$16 \mathrm{~F}$} & 1 & 0 & $\mathbf{N}$ & $7 \cdot 6$ & $1 \cdot 4$ & 15 & $11 \cdot 6$ & $8 \cdot 4$ & - & 225 & 35 \\
\hline & 1 & 0 & $\mathbf{N}$ & $7 \cdot 6$ & 1.4 & 52 & 39 & $8 \cdot 8$ & - & 280 & 30 \\
\hline & 1 & o & $\mathbf{N}$ & $7 \cdot 6$ & 1.4 & 39 & 52 & $8 \cdot 6$ & - & 320 & 25 \\
\hline & 1 & 0 & $\mathbf{N}$ & $7 \cdot 6$ & 1.4 & 30 & 57 & $8 \cdot 3$ & - & 335 & 20 \\
\hline \multirow[t]{8}{*}{81} & o & 0 & $\mathbf{N}$ & $7 \cdot 6$ & 0.72 & 0 & 0 & - & - & 0 & 35 \\
\hline & 0 & 0 & $\mathbf{N}$ & $7 \cdot 6$ & 0.72 & 0 & 0 & - & - & 0 & 30 \\
\hline & 0 & 0 & $\mathbf{N}$ & $7 \cdot 6$ & 0.72 & 0 & $5 \cdot 7$ & - & - & 205 & 25 \\
\hline & 0 & 0 & $\mathbf{N}$ & $7 \cdot 6$ & 0.72 & 0.6 & 1.6 & - & - & 113 & 20 \\
\hline & 0.1 & 0.03 & $\mathbf{N}$ & $7 \cdot 0$ & 0.72 & 0 & 0 & - & - & 0 & 35 \\
\hline & $0 \cdot 1$ & 0.03 & $\mathbf{N}$ & $7 \cdot 0$ & 0.72 & 0 & 0 & $7 \cdot 5$ & - & 87 & 30 \\
\hline & $0 \cdot 1$ & 0.03 & $\mathbf{N}$ & $7 \cdot 0$ & 0.72 & $5 \cdot 5$ & 20 & $7 \cdot 7$ & - & 390 & 25 \\
\hline & $0 \cdot 1$ & $0 \cdot 03$ & $\mathbf{N}$ & $7 \cdot 0$ & 0.72 & $3 \cdot 7$ & $8 \cdot 9$ & $7 \cdot 5$ & - & 335 & 20 \\
\hline \multirow[t]{4}{*}{$16 \mathrm{~F}$} & 1 & 0 & $\mathbf{P}$ & $7 \cdot 5$ & 1.5 & 35 & 82 & $8 \cdot 5$ & - & 340 & 25 \\
\hline & 1 & 0 & $\mathbf{N}$ & $7 \cdot 5$ & $1 \cdot 5$ & 20 & 27 & $8 \cdot 8$ & - & 340 & - \\
\hline & 0.1 & 0.03 & $\mathbf{P}$ & $7 \cdot 0$ & 1.4 & 19 & 27 & - & - & 250 & - \\
\hline & $0 \cdot 1$ & 0.03 & $\mathbf{N}$ & $7 \cdot 0$ & 1.4 & 11 & 12 & $7 \cdot 9$ & - & 290 & - \\
\hline \multirow[t]{2}{*}{81} & $0 \cdot 1$ & 0.03 & $\mathbf{P}$ & $7 \cdot 0$ & 0.94 & $3 \cdot 7$ & 7 & 7.5 & - & 180 & - \\
\hline & 0 & 0 & $\mathbf{G a}$ & $7 \cdot 5$ & 0.75 & $1 \cdot 7$ & 0.6 & - & - & 80 & - \\
\hline
\end{tabular}

$\mathbf{G}=$ glucose $; \mathbf{N}=$ sodium pectate $\mathbf{P}=$ pectin $; \mathbf{G a}=$ galacturonic acid. Where two estimates of bacterial numbers are given these were made by the Miles \& Misra technique, otherwise the $48 \mathrm{hr}$. count was made nephelometrically.

Flavobacterium pectinovorum isolate 81 grown in a medium containing sodium pectate $1 \%(\mathrm{w} / \mathrm{v})$ as sole carbon source, at $\mathrm{pH} 7 \cdot 5$, and one containing sodium pectate $1 \%(\mathrm{w} / \mathrm{v})+0 \cdot 1 \%$ peptone $+0.03 \%$ yeast extract at $\mathrm{pH} 7 \cdot 0$; and with Erwinia carotovora $16 \mathrm{~F}$ grown on sodium pectate $1 \%+1 \%$ peptone $(\mathrm{pH} \mathrm{7 \cdot 5)}$. Growth at $35^{\circ}, 30^{\circ}, 25^{\circ}$ and $20^{\circ}$ was studied; all flasks were duplicated. E. carotovora $16 \mathrm{~F}$ produced enzyme at all temperatures, though much less at $35^{\circ}$; 
isolate 81 died out at $35^{\circ}$, and only grew at $30^{\circ}$ in the peptone-containing medium; enzyme was only produced at $25^{\circ}$ and $20^{\circ}$.

The influence of the rate of shaking was studied with Flavobacterium pectinovorum isolate 81 in a medium containing sodium pectate $1 \%(\mathrm{w} / \mathrm{v})$ at $\mathrm{pH} \mathrm{7.5}$ and on one containing sodium pectate $1 \%+1 \%$ peptone at $\mathrm{pH} 6 \cdot 2$. Three different conditions of shaking were used: static and shaken at 60 or 90 strokes/ min. (normally 100). Both growth and enzyme production were greatly enhanced at the higher rates. Pectin was compared with sodium pectate as an inducer of polygalacturonase formation when incorporated into medium containing peptone $0.1 \%(\mathrm{w} / \mathrm{v})$ and yeast extract $0.03 \%(\mathrm{w} / \mathrm{v})$. Erwinia carotovora $16 \mathrm{~F}$ produced more enzyme in the pectin-containing medium, while $F$. pectinovorum isolate 81 produced more in the sodium pectate medium. Lastly, isolate 81 was inoculated into a medium containing Seitz-filtered $1 \%(\mathrm{w} / \mathrm{v})$ galacturonic acid as sole carbon source, with inorganic salts, at $\mathrm{pH} 7.5$; it produced enzyme after $24 \mathrm{hr}$., but this disappeared after a further $24 \mathrm{hr}$. incubation.

Heavy crops of Flavobacterium pectinovorum isolate 81 were grown in media containing peptone or peptone + glucose; washed suspensions of these organisms were incubated and shaken in the presence of sodium pectate. These suspensions became adapted to produce polygalacturonase; the period needed for adaptation was 24-48 hr., longer than would be required to grow a crop of organisms from a small inoculum. In pectate-containing media isolate 81 preserved the normal rod shape even after a month of incubation, but when grown in yeast extract medium the organisms became long (up to $50 \mu$ ) and irregular in shape and staining properties within $24 \mathrm{hr}$. The failure of these organisms to adapt quickly to produce polygalacturonase might be connected with the presence of these involution forms.

\section{Studies of the polygalacturonase produced by Flavobacterium pectinovorum isolate 81}

Culture filtrates of Flavobacterium pectinovorum isolate 81 were studied to determine the properties of the pectic enzyme present, and culture filtrates of Erwinia carotovora isolate $16 \mathrm{~F}$ were compared with these. Samples of culture fluids from isolate $\mathbf{8 1}$ grown under a range of conditions were tested for the presence of pectin methyl esterase, and were all found negative. Three isolates of $\boldsymbol{E}$. carotovora and one of Xanthomonas campestris all produced the esterase when grown on a pectin-containing medium. It was therefore concluded that $\boldsymbol{F}$. pectinovorum isolate 81 produced no pectin methyl esterase, but only a hydrolytic polygalacturonase type of enzyme or enzymes.

The initial stages of breakdown of pectin by polygalacturonase were followed viscometrically. Ten $\mathrm{ml}$. of $1.5 \%(\mathrm{w} / \mathrm{v})$ purified pectin solution was mixed with $5 \mathrm{ml} .0 \cdot 2 \mathrm{M}$-tris buffer ( $\mathrm{pH} \mathrm{8.0}$ ), $2 \mathrm{ml} .0 \cdot 1 \mathrm{M}-\mathrm{CaCl}_{2}$ and $3 \mathrm{ml}$. diluted culture fluid. The initial relative viscosity was $c .5$ units, decreasing to 1.5 in $30 \mathrm{~min}$. with active preparations. Enzyme preparations were diluted until it was possible to make an accurate measurement of the initial rate of viscosity decrease, and at high dilutions this rate was proportional to the enzyme 
concentration (Fig. 1). Using this graphic method an estimate of the relative strength of two different enzyme preparations was obtained (Fig. 2).

Twofold dilutions in tris buffer of culture filtrates of Erwinia carotovora $16 \mathrm{~F}$ and Flavobacterium pectinovorum isolate 81 were tested by the spine plate method. Each dilution up to $1 / 256$ was tested on two plates with 12 fishspines/plate. The mean diameters of the clear zones were measured. When the square of the radius of the clear zone was plotted against the log of enzyme concentration, the data for isolate 81 fell on a straight line (fig. 3). The lowest

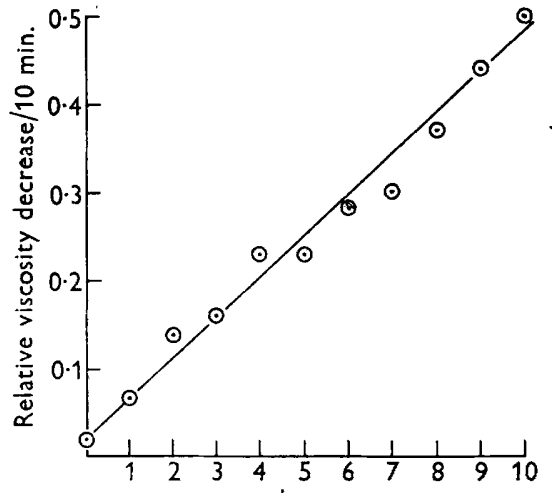

$\mathrm{ml}$. culture fluid $/ 20 \mathrm{ml}$. pectin solution

Fig. 1

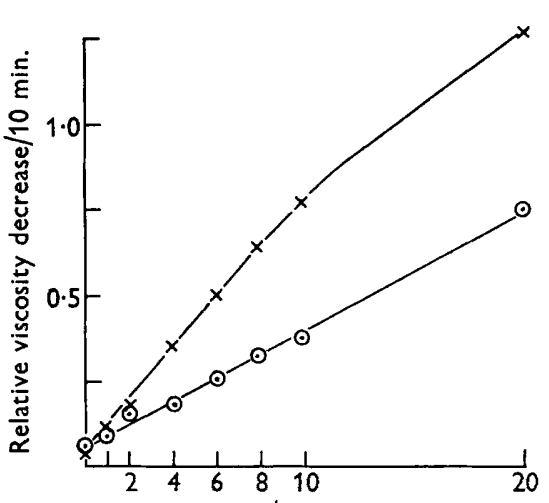

$\mathrm{ml}$. culture fluid $/ 20 \mathrm{ml}$. pectin solution

Fig. 2

Fig. 1. Initial rate of pectin breakdown (followed viscometrically) plotted against concentration of Flavobacterium pectinovorum polygalacturonase.

Fig. 2. As Fig. 1. Erwinia carotovora polygalacturonase, $\times$; Flavobacterium pectinovorum polygalacturonase $\odot$.

Flavobacterium pectinovorum was grown in a medium containing sodium pectate $1 \%$ $(\mathrm{w} / \mathrm{v}), 0.1 \%$ peptone and $0.03 \%$ yeast extract; Errvinia carotovora in $1 \%(\mathrm{w} / \mathrm{v})$ sodium pectate and $1 \%$ peptone.

dilution produced a readable response, and the controls (autoclaved enzyme) no response at all. The data for $\boldsymbol{E}$. carotovora $16 \mathrm{~F}$, however, presented a more complex picture; in particular the angle of slope became greater at higher enzyme concentrations, so giving a false impression of high potency. The two samples of culture filtrate from isolates $16 \mathrm{~F}$ and 81 , respectively, which had been carefully assessed by the viscometric method, were tested by serial dilution on fish-spine plates, after the $16 \mathrm{~F}$ sample, which was the stronger, had first been diluted to a potency equivalent to the sample of isolate 81 filtrate. The results are graphed in Fig. 4. Isolate 81 filtrate again gave a straight line while $\boldsymbol{E}$. carotovora $16 \mathrm{~F}$ filtrate showed a distinct curve; but the two solutions gave almost the same readings where the diameter of the clear zone was $c$. $10 \mathrm{~mm}$. Graphs of this type were used to derive the spine plate units (SPU) of enzyme present in test solutions, assuming that a solution of potency 1 unit produces a $10 \mathrm{~mm}$. diameter clear zone. The width of the opaque annulus surrounding the clear zone on the spine plate varied considerably; it was not directly correlated with the presence of pectin methyl esterase in the test 
solution. At higher potencies the spine-plate test is less accurate, and dilution down to a range of 1-10 SPU is recommended.

The hypoiodite method for the determination of release of reducing groups (Jansen \& MacDonnell, 1945; Kraght \& Starr, 1953) was used as a check on the other two methods. The method followed was the same as Kraght \& Starr's, but with the sodium pectate dissolved in tris buffer ( $\mathrm{pH} \mathrm{8)}$. Culture fluids of Erwinia carotovora $16 \mathrm{~F}$ liberated $0.03 \mathrm{~m}$-equiv. reducing groups/ $30 \mathrm{~min}, / 2.5 \mathrm{ml}$. culture filtrate, flavobacterium isolate $810.02 \mathrm{~m}$-equiv. These figures are near those quoted by Kraght \& Starr.

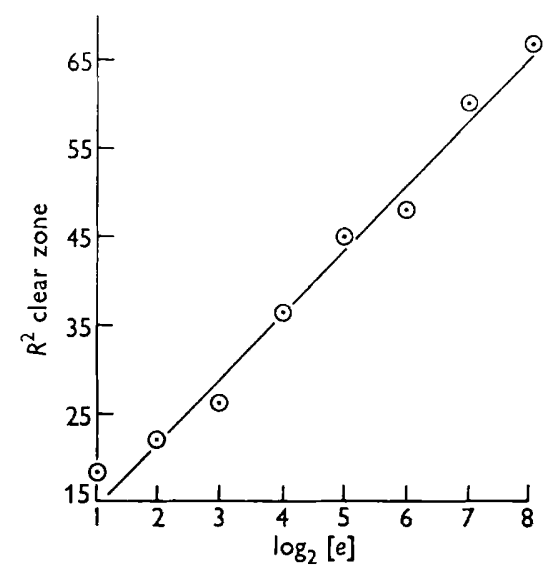

Fig. 3

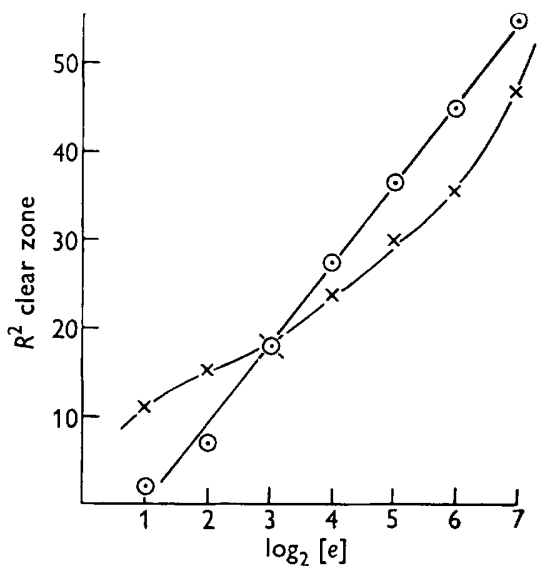

Fig. 4

Fig. 3. Area of clear zone on spine plate plotted against serial $50 \%$ dilutions of Flavobacterium pectinovorum polygalacturonase.

Fig. 4. As Fig. 3. Erwinia carotovora polygalacturonase, $\times$; Flavobacterium pectinovorum polygalacturonase, $\odot$.

The calcium requirement of the polygalacturonase of Flavobacterium pectinovorum was most readily demonstrated viscometrically; increasing calcium concentrations up to $0.01 \mathrm{M}$ resulted in increased enzyme activity. Demonstration of this by the spine-plate technique proved difficult since agar itself is a calcium salt and the addition of yet more calcium only decreased enzyme activity. Silica gel was used instead of agar gel and, provided that the culture fluid itself was rigorously freed from calcium, it could be shown that polygalacturonase activity was negligible in the absence of calcium.

The $\mathrm{pH}$ range of the enzyme was studied by the spine-plate and viscometric techniques; the spine-plate test showed a broad optimum between $\mathrm{pH} 7 \cdot 4$

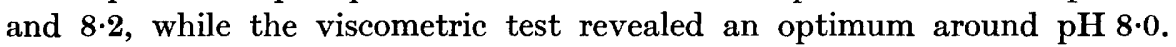
At $\mathrm{pH} 8.5$ the control showed a rapid decrease in viscosity which more than offset the slightly increased rate of enzymic action.

The temperature optimum for the enzymic reaction was distinctly higher than that which allowed growth of Flavobacterium pectinovorum isolate 81; $37^{\circ}$ was optimal but even at $45^{\circ}, 1 / 10$ of the activity remained. Erwinia carotovora $16 \mathrm{~F}$ was compared with the flavobacterium; for the erwinia the optimum temperature was $40^{\circ}$. Table 3 records these observations. 
Table 3. Temperature relations of the polygalacturonases of Erwinia carotovora $16 \mathrm{~F}$ and Flavobacterium pectinovorum isolate 81

Temp.
$\left({ }^{\circ}\right)$
25
30
37
40
43
45
50

\begin{tabular}{cc}
\multicolumn{2}{c}{ E. carotovora $16 \mathrm{~F}$} \\
\hline $\begin{array}{c}\text { Apparent } \\
\text { SPU* }\end{array}$ & $\begin{array}{c}\% \text { of } \\
\text { maximum }\end{array}$ \\
$2 \cdot 7$ & 47 \\
$3 \cdot 75$ & 65 \\
$4 \cdot 6$ & 79 \\
$4 \cdot 8$ & 100 \\
1.3 & 22 \\
0.93 & 16 \\
0.16 & 3
\end{tabular}

\begin{tabular}{|c|c|}
\hline $\begin{array}{l}\text { Apparent } \\
\text { SPU }\end{array}$ & $\begin{array}{c}\% \text { of } \\
\text { maximum }\end{array}$ \\
\hline $1 \cdot 3$ & 28 \\
\hline $2 \cdot 3$ & 40 \\
\hline $4 \cdot 6$ & 100 \\
\hline 1.8 & 39 \\
\hline 0.81 & 18 \\
\hline 0.43 & 9 \\
\hline $0 \cdot 13$ & 3 \\
\hline
\end{tabular}

* SPU $=$ spine plate units.

\section{DISCUSSION}

The pectic enzymes produced by Flavobacterium pectinovorum and Erwinia carotovora, and that of Bacterium aroideae (Wood, 1955), appear to be of the same general type. A new classification of pectic enzymes has been proposed (Demain \& Phaff, 1957). According to this the bacterial polygalacturonases are classified as Endopolymethylgalacturonase II, signifying that they hydrolyse their substrate in a random fashion and attack pectin in preference to pectic acid; the enzyme produced by Bacterium aroideae (Wood, 1955) is given as the example of this group. However, all these enzymes readily attack pectic acid, and indeed Wood showed that the $B$. aroideae enzyme hydrolysed pectic acid faster than pectin under his conditions. When a preference for pectic acid is conclusively proved (and providing the culture fluids used do not contain a mixture of polygalacturonases), the enzyme would need to be reclassified as an Endopolygalacturonase II. The very rapid viscosity-decrease of pectin solutions attacked by an enzyme certainly signifies random rather than terminal hydrolysis. The hydrolysis of pectic acid cannot be properly studied in this way since it gels in the presence of the calcium required by the enzyme; however, these gels disperse rapidly (Wood, 1955).

Although the polygalacturonases of Erwinia carotovora $16 \mathrm{~F}$, and Flavobacterium isolate 81 are similar in performance, their mode of production is distinct. It was not found possible to produce the enzyme of isolate 81 in the absence of pectin or pectic acid (i.e. the substrates) or galacturonic acid (the end product of the reaction), but the enzyme of $E$. carotovora $16 \mathrm{~F}$ was produced constitutively in moderate amounts (up to $20 \%$ of the maximum) in any medium in which it grew actively. Wood (1955) did not grow his organism in a medium containing pectic material, and did not observe whether pectic substances enhanced enzyme production; this may account for his failure to produce pectin methyl esterase. Under optimal conditions $E$. carotovora $16 \mathrm{~F}$ produced about twice as much enzyme as isolate 81 , measured by the spine plate technique. 
The production of pectin methyl esterase by Erwinia carotovora and the closely related organism, Bacterium aroideae (Syn. Erwinia aroideae; Rudd Jones, 1950) has been the subject of disagreement. Kraght \& Starr (1953) did not prove conclusively that $\boldsymbol{E}$. carotovora produced pectin methyl esterase; the methanol which they found in culture filtrates might have been produced by fermentation of the galacturonic acid. Wood did not find esterase activity in his cultures, but Smith (1958) tested strains of $E$. carotovora and $E$. aroideae and found that they all produced pectin methyl esterase. This has been confirmed in the present work.

The viscometric technique and the hypoiodite method for the determination of reducing groups have been used frequently in polygalacturonase studies (Kertesz, 1951). The spine-plate test is supplementary to these; in effect it measures the amount of sodium pectate which is no longer precipitable by acid after the action of enzyme; its virtue lies in its ease and simplicity, and in the possibility of performing the test on very small amounts of enzyme.

The Flavobacterium sp. described in this paper is only one of many types of pectolytic organism present in soil. It is distinguished, however, by its ability to grow on pectic substances as a sole carbon source, and by its inducible polygalacturonase. The absence of a pectin methyl esterase would not prevent the organisms from attacking plant pectins in the soil, since most plant material contains a pectin methyl esterase which de-esterifies the pectin during senescence.

The author wishes to thank all those who kindly contributed cultures and information, and Professor B. C. J. G. Knight for his advice.

\section{REFERENCES}

Demain, A. L. \& Phaff, H. J. (1957). Recent advances in the enzymatic hydrolysis of pectic substances. Wallerstein Lab. Commun. $20,119$.

Dingle, J., Reid, W. W. \& Solomons, G. L. (1953). The enzymatic degradation of pectin and other polysaccharides. II. Application of the 'cup-plate' assay to the estimation of enzymes. J. Sci. Fd Agric. 4, 149.

JANSEN, E. F. \& MACDonnell, L. R. (1945). The methoxyl content of pectins and polygalacturonase. Arch. Biochem. 8, 97.

Kerr, A. (1953). A method of isolating soft-rotting bacteria from soils. Nature, Lond. 172, 1155.

Kertesz, Z. I. (1951). The Pectic Substances. New York: Interscience Publishers.

Kraght, A. J. \& Starr, M. P. (1953). Pectic enzymes of Ervinia carotovora. Arch. Biochem. Biophys. 42, 271.

LeEs, H. (1949). The soil percolation technique. Plant \& Soil, 1, 221.

Miles, A. A. \& Misra, S. S. (1938). The estimation of the bactericidal power of the blood. J. Hyg., Camb. 38, 732.

Proom, H., Woiwod, A. J., Barnes, J. M. \& Orbell, W. G. (1950). A growthinhibitory effect on Shigella dysenteriae which occurs with some batches of nutrient agar and is associated with the production of peroxide. J. gen. Microbiol. 4, 270.

Richards, T. \& Fouad, M. T. A. (1954). The use of glucose-inorganic salts media in the classification of the coli-aerogenes bacteria. II. The indole test and pectate gel liquefaction. J. appl. Bact. 17, Proc. 19. 
Rondle, C. J. M. \& Carman, B. J. (1956). Agar diffusion plates: the recording of experimental data. Experientia, 12, 443.

RuDd, Jones, D. (1950). On the nomenclature and identity of the coliform softrot bacteria. Trans. Brit. mycol. Soc. 33.

Sмiтн, W. K. (1951) The ion-exchange method of preparing silica sols. Proc. Soc. appl. Bact. 14, 139.

SмIтн, W. K. (1958). A survey of the production of pectic enzymes by plant pathogenic and other bacteria. J. gen. Microbiol. 18, 33.

WeEks, O. B. (1955). Flavobacterium aquatile (Frankland and Frankland) Bergey et al., type species of the genus Flavobacterium. J. Bact. 69, 649.

Wieringa, K. T. (1949). A method for isolating and counting pectolytic microbes. Proc. 4th int. Congr. Microbiol., Copenhagen, p. 482.

Woov, R. K. S. (1955). Studies in the physiology of parasitisms XVIII. Pectic enzymes secreted by Bacterium aroideae. Ann. Bot. Lond. N.S. 19, 1.

ZINN, M. K. (1955). A study on some organic nitrogen compounds of soils. Ph.D. Thesis, University of Reading.

(Received 4 July 1958) 